УДК 54.062

В.В. СВТУШЕНКО, О. О. СЕМЕНЧЕНКО

Херсонський національний технічний університет

\title{
ДОСЛІДЖЕННЯ ЯКОСТІ ШАМПУНІВ РІЗНИХ ТОРГОВЕЛЬНИХ МАРОК
}

\author{
В.В. ЕВТУШЕНКО, О.А. СЕМЕНЧЕНКО
}

Херсонский национальный технический университет

\section{ИССЛЕДОВАНИЕ КАЧЕСТВА ШАМПУНЕЙ РАЗНЫХ ТОРГОВЫХ МАРОК}

\author{
V. EVTUSHENKO, O. SEMENCHENKO
}

Kherson National Technical University

\section{QUALITY RESEARCH OF SHAMPOOS OF DIFFERENT TRADEMARKS}

\author{
https://doi.org/10.36910/6775-2310-5283-2019-12-10
}

\begin{abstract}
Мета. Метою роботи є дослідження якості шампунів різної дії вітчизняних та закордонних виробників, які реалізуються в торгівельних мережах м. Херсона.

Методика. Дослідження проводились за допомогою стандартних методик, викладених у діючих нормативних документах: органолептичні показники якості визначались відповідно до методики, викладеної у ДСТУ 5009:2008; фізико-хімічні показники, з-окрема, водневий показник та піноутворювальна здатність - відповідно до ДСТУ ISO 696:2005.
\end{abstract}

Результати. Для дослідження якості шампунів було обрано вісім зразків різних виробників, які користуються попитом у спожсивачів та призначені для різних типів волосся TM «AVON», "L'Oreal Paris», «Schauma», «Fitoval», "Head \& shoulders», "Natural Spa», "NATURE.med», Gliss Kur. За проведеною оцінкою якості встановлено, щуо за органолептичними показниками - зовнішнім виглядом та кольором всі зразки відповідають вимогам діючого вітчизняного стандарту, за запахом два зразки не відповідають згідно зі складом та назвою. За фізико-хімічними показниками всі зразки шампунів відповідають встановленим вимогам. Однак, за водневим показником відповідно до рекомендацій щуодо типу волосся деякі зразки мають низькі значення. На маркуванні шампунів жоден із виробників не вказав рівню $\mathrm{pH}$, а виробники трьох зразків шампунів не зазначили частоту використання в залежності від типу волосся. Виробники всіх зразків шампунів, окрім одного, не вказали на маркуванні нормативний документ відповідно до якого виготовлено дану продукцію.

Вимоги щуодо якості шампунів доцільно формувати й оцінювати із врахуванням водневого показника шампунів відповідно до типу волосся. Пропонується в перспективі дослідження споживних властивостей шампуню із врахуванням фізико-хімічних характеристик відповідно до типу волосся.

Наукова новизна. Встановлено необхідність проведення досліджень якості шампуню із врахуванням водневого показника відповідно до типу волосся.

Практична значимість. Запропоновані дослідження можуть бути використані 
під час сертифікаиіі шампуню та внесені у діючі нормативні документи. Зокрема, в загальних технічних умовах, доцільним $\epsilon$ внесення значень водневого показника в залежності від типу волосся для якого призначені шампуні.

Ключові слова: шампунь, якість, показники якості, водневий показник, типи волосся, вимоги.

Постановка проблеми у загальному вигляді та її зв'язок із важливими науковими чи практичними завданнями. Ринок шампунів в Україні має тенденцію до невеликого щорічного скорочення на 1-2\%. Це відбувається через постійне зменшення чисельності населення нашої країни. Ще одним трендом останніх років стало поступове витіснення шампунів українського виробництва імпортною продукцією. Причинами $\epsilon$ переорієнтація частини споживачів на більш дорогі брендові шампуні в поєднанні зі зростанням собівартості внутрішнього виробництва через подорожчання імпортних інгредієнтів. В даний час частка імпорту на ринку приблизно в два рази перевищує частку українських шампунів [1].

Широкий асортимент шампунів різної дії, представлених на вітчизняному ринку, не завжди відповідає попиту споживачів, тому питання дослідження їх якості є актуальним.

Аналіз останніх досліджень, у яких започатковано вирішення проблеми. Шампунь є одним із найбільш поширених косметичних засобів по догляду за волоссям, яким користується велика кількість споживачів. У зв'язку з цим останнім часом значна увага приділяється розширенню його асортименту за рахунок зміни його рецептури, використання нових технологій під час виробництва. Значна увага приділяється упаковці та маркуванню [2]. Проведено ряд досліджень впливу якості пакування на конкурентоспроможність косметичних засобів, зосереджуючи увагу на потребі перегляду нормативів до пакування та зберігання продукції [3]. Авторами ордіяка Ю.М., Міхалєвою М.С. та Байцар Р.І. здійснено експериментальне дослідження впливу твердості води на реологічні властивості піномийних косметичних засобів та обгрунтовано необхідність перегляду їх нормативного складу на відповідність стандартним показникам $[4,5]$. Проведений аналіз свідчить про те, що на сьогоднішній день вченими приділяється мало уваги дослідженню якості шампуню, тому проведені дослідження є актуальними.

Цілі статті. Метою роботи є дослідження якості шампунів різної дії різних виробників, які реалізуються на ринку м. Херсона.

Об’єкт дослідження: шампунів різних виробників. 
Методи дослідження. Дослідження проводились за допомогою стандартних методик, викладених у діючих нормативних документах та відповідного лабораторного обладнання.

Виклад основного матеріалу дослідження 3 повним обгрунтуванням отриманих наукових результатів. Для дослідження якості шампунів було обрано вісім зразків різних виробників, які користуються попитом у споживачів та призначені для різних типів волосся. Обрані зразки мали наступні характеристики.

Зразок №1. Шампунь TM «AVON» Naturals для слабкого та ламкого волосся з екстрактом кропиви та лопуха. Виробник: ВАТ «Эйвон Бьюти Продакс Компани», Росія. Імпортер: ДП Ейвон Косметікс Юкрейн, Україна.

Зразок №2. Шампунь TM «Natural Spa» проти лупи 3 кропивою та шавлією. Виробник ТОВ «ФНИЦ» «Альянс краси», Україна.

Зразок №3. Шампунь TM «L'Oreal Paris» ELSEVE HAIRCARE для захисту кольору. Виробник: Фапрореаль, Франція. Імпортер: ТОВ «Лореаль Україна».

Зразок №4. Шампунь TM «NATURE.med. Цибулево-часниковий комплекс для волосся. Для сухого та пошкодженого волосся». Виробник: ТОВ «Георг Биосистеми», Україна.

Зразок №5. Шампунь TM «Gliss Kur зимовий захист». Виробник: Шварцкопф \& Хенкель Продакшен Юроп ГмбХ\&Ко, КГ, Німеччина. Імпортер: ТОВ «Хенкель Україна», Україна.

Зразок №6. Шампунь ТM «Schauma» для чоловіків для слабкого та ламкого волосся. Виробник: Шварцкопф \& Хенкель Продакшен Юроп ГмбХ\&Ко, КГ, Німеччина. Імпортер: ТОВ «Хенкель Україна», Україна.

Зразок №7. Шампунь TM «Fitoval» дерматологічний для пошкодженого волосся. Виробник: КРКА, д. д., Ново место, Словенія. Імпортер ТОВ «КРКА Україна», Україна.

Зразок №8. Шампунь ТМ «Неad \& shoulders» проти лупи основний догляд. Виробник: Procter \& Gamble, Румунія. Імпортер: TOB «Procter \& Gamble Україна», Україна.

Всі зразки шампунів було досліджено за органолептичними та фізикохімічними показниками. Результати проведених досліджень наведено в таблиці 1.

Органолептичні показники якості визначались відповідно до методики, викладеної у ДСТУ 5009:2008 [6]. За зовнішнім виглядом та кольором всі 
зразки відповідали вимогам ДСТУ 4315:2004 [7], а за запахом зразки №4 та №6 не відповідали вимогам стандарту та запаху відповідно до складу.

Таблиця 1

Дослідження органолептичних та фізико-хімічних

показників шампунів

\begin{tabular}{|c|c|c|c|c|c|c|}
\hline \multirow{3}{*}{$\begin{array}{l}\text { Назва } \\
\text { зразка }\end{array}$} & \multicolumn{6}{|c|}{ Показники якості } \\
\hline & \multirow{2}{*}{$\begin{array}{c}\text { зовнішній } \\
\text { вигляд }\end{array}$} & \multirow{2}{*}{ запах } & \multirow{2}{*}{ колір } & \multirow{2}{*}{$\begin{array}{l}\text { водневий } \\
\text { показник } \\
\text { (рН), од. }\end{array}$} & \multicolumn{2}{|c|}{$\begin{array}{c}\text { піноутворювальна } \\
\text { здатність }\end{array}$} \\
\hline & & & & & $\begin{array}{l}\text { пінне } \\
\text { число }\end{array}$ & $\begin{array}{c}\text { стійкість } \\
\text { піни }\end{array}$ \\
\hline $\begin{array}{l}\text { Зразок } \\
\text { №1 }\end{array}$ & $\begin{array}{c}\text { однорідна } \\
\text { драглеподібна } \\
\text { маса } 3 \\
\text { перламутром }\end{array}$ & $\begin{array}{c}\text { природний } \\
\text { трав'яний }\end{array}$ & $\begin{array}{c}\text { світло- } \\
\text { зелений }\end{array}$ & 5,95 & 156 & 0,91 \\
\hline $\begin{array}{l}\text { Зразок } \\
\text { №2 }\end{array}$ & $\begin{array}{c}\text { однорідна } \\
\text { драглеподібна } \\
\text { маса }\end{array}$ & $\begin{array}{c}\text { із запахом } \\
\text { кропиви }\end{array}$ & салатний & 6,05 & 130 & 0,88 \\
\hline $\begin{array}{l}\text { Зразок } \\
\text { №3 }\end{array}$ & $\begin{array}{c}\text { однорідна } \\
\text { драглеподібна } \\
\text { маса }\end{array}$ & $\begin{array}{c}\text { із запахом } \\
\text { льону }\end{array}$ & білий & 5,08 & 150 & 0,87 \\
\hline $\begin{array}{l}\text { Зразок } \\
\text { №4 }\end{array}$ & $\begin{array}{c}\text { однорідна } \\
\text { драглеподібна } \\
\text { маса }\end{array}$ & $\begin{array}{c}\text { не } \\
\text { приємний, } \\
\text { різкий }\end{array}$ & жовтий & 6,08 & 168 & 0,93 \\
\hline $\begin{array}{l}\text { Зразок } \\
\text { №5 }\end{array}$ & $\begin{array}{c}\text { однорідна } \\
\text { драглеподібна } \\
\text { маса } 3 \\
\text { перламутром }\end{array}$ & приємний & $\begin{array}{c}\text { сріблясто- } \\
\text { білий }\end{array}$ & 4,28 & 200 & 0,85 \\
\hline $\begin{array}{l}\text { Зразок } \\
\text { №6 }\end{array}$ & $\begin{array}{c}\text { однорідна } \\
\text { драглеподібна } \\
\text { маса } 3 \\
\text { перламутром }\end{array}$ & $\begin{array}{l}\text { свіжий, } \\
\text { хвойний }\end{array}$ & $\begin{array}{l}\text { сріблясто- } \\
\text { білий }\end{array}$ & 4,56 & 167 & 0,87 \\
\hline $\begin{array}{l}\text { Зразок } \\
\text { №7 }\end{array}$ & $\begin{array}{c}\text { однорідна } \\
\text { драглеподібна } \\
\text { маса }\end{array}$ & $\begin{array}{c}\text { квітковий } \\
\text { аромат }\end{array}$ & кремовий & 5,70 & 160 & 0,96 \\
\hline $\begin{array}{l}\text { Зразок } \\
\text { №8 }\end{array}$ & $\begin{array}{c}\text { однорідна } \\
\text { драглеподібна } \\
\text { маса } 3 \\
\text { перламутром }\end{array}$ & $\begin{array}{l}\text { тропічні } \\
\text { фрукти }\end{array}$ & блакитний & 6,50 & 154 & 0,94 \\
\hline
\end{tabular}


Дослідження за фізико-хімічними показниками включало визначення

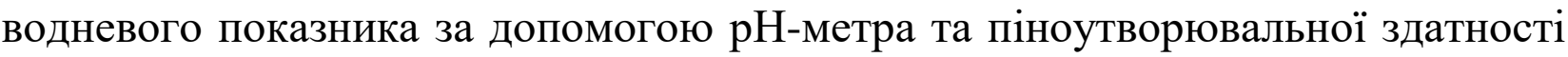
відповідно до методики, викладеної у ДСТУ ISO 696:2005 [8].

Аналіз отриманих результатів дозволяє зробити висновок, що водневий показник $\mathrm{pH}$ у всіх зразках відповідає вимогам ДСТУ 4315:2004 [7] та знаходиться в межах норми, яка регламентується в стандарті: 3,5-8,5.

Піноутворювальна здатність шампунів характеризується пінним числом та стійкістю піни, які також знаходяться в межах норми: не менше 145 та в межах 0,8-1 відповідно. Отже, за фізико-хімічними показниками всі зразки шампунів відповідали вимогам діючого вітчизняного стандарту.

Для проведення досліджень було обрано зразки шампунів для різних типів волосся та різного призначення, тому доцільним було проведення аналізу отриманих значень водневого показника, оскільки рівень кислотності шампуню відіграє важливу роль у догляді за волоссям та може впливати на стан шкіри голови.

Так, наприклад, для сухого, ослабленого та пошкодженого волосся рекомендуються кислі шампуні з пониженим вмістом лугів 3 pH 5,5-7,0 або взагалі без лугів з $\mathrm{pH}$ 4,5-5,5. Це пов'язано з тим, що фарбування та хімічне завивання змінюють баланс волосся у лужне середовище, що призводить до їх ламкості та посіченості. Кислі шампуні також підходять для усунення та запобігання появи лупи [9]. Зразки шампунів №1, 4, 6, 7 призначені для слабкого, ламкого та пошкодженого волосся мають рівень $\mathrm{pH}$ в межах 4,566,08 та зразки №2 та №8 проти лупи відповідно 6,05 та 6,50. Отримані результати відповідають рекомендаціям щодо рівня кислотності. Зразки №3 та №5 призначені для нормального волосся та захисту їх кольору й захисту волосся зимою мають відповідно рівень $\mathrm{pH}=5,08$ та $\mathrm{pH}=4,28$ що свідчить про кисле середовище. Однак, для нормального волосся рекомендовано

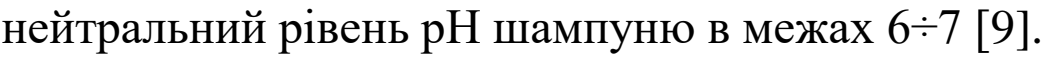

Жирне волосся тонке, позбавлене об'єму, шкіра в надлишку виділяє шкірний жир. Тому для такого волосся рекомендується використовувати шампуні з нейтральним або лужним балансом $(\mathrm{pH}=6-8)$ [9]. Шампуні для жирного волосся дуже «агресивно» очищують шкіру голови, висушуючи іiі i змушують сальні залози виробляти ще більше шкіряного жиру. Регулярне застосування такого шампуню викликає свербіж, лущення, лупу, волосся залишається жирним. Для дітей потрібно вибирати тільки нейтральні шампуні. 
Не всі виробники шампунів вказують на упаковках рівень $\mathrm{pH}$, вважаючи, що рекомендацій щодо застосування засобу для миття достатньо. У нашому випадку жоден із виробників не вказав на упаковці рівень $\mathrm{pH}$ шампуню. Необхідно зазначити, що виробники зразків шампунів №1, 2 №4 та №7 не дають рекомендацій щодо частоти використання шампунів. Виробники всіх зразків шампунів, окрім виробника зразка №4, не вказали на маркуванні нормативний документ відповідно до якого виготовлено дану продукцію.

Висновки та перспективи подалыших досліджень. За проведеною оцінкою якості зразків шампуню встановлено, що за органолептичними показниками - зовнішнім виглядом та кольором всі зразки відповідають вимогам діючого вітчизняного стандарту, за запахом зразки № 4 та №6 не відповідають відповідно до складу та назви. За фізико-хімічними показниками всі зразки шампунів відповідають встановленим вимогам. Однак, за водневим показником $\mathrm{pH}$ відповідно до рекомендацій щодо типу волосся зразки №3 та №5 мають низькі значення.

На маркуванні шампунів жоден із виробників не вказав рівню $\mathrm{pH}$, а виробники зразків №1, 2 №4 та №7 не зазначили частоту використання в залежності від типу волосся. Виробники всіх зразків шампунів, окрім виробника зразка №4, не вказали на маркуванні нормативний документ відповідно до якого виготовлено дану продукцію.

Вимоги щодо якості шампунів доцільно формувати й оцінювати iз врахуванням водневого показника відповідно до типу волосся. Пропонується в перспективі дослідження споживних властивостей шампуню із врахуванням фізико-хімічних властивостей відповідно до типу волосся.

\section{Список використаних джерел}

1. Якість перемагає ціну: аналіз ринку шампунів в Україні https:/proconsulting.ua/ua/pressroom/kachestvo-pobezhdaet-cenu-analiz-rynka-shampunej-v-ukraine

2. Щепакін, М. Б. Аналіз тенденцій розвитку парфумово-косметичного ринку України [Текст] / М. Б. Щепакін, М. С. Якунчева // Бізнес. - 2010. - № 4. - С. 15-16.

3. Байцар P.I. Актуальні проблеми та перспективи розвитку косметичної галузі / P.I. Байцар, Ю.М. Кордіяка // Вісник Національного університету «Львівська політехніка» Автоматика, вимірювання та керування. - 2015. - № 821. - С. 44-50.

4. Кордіяка Ю.М. Нормовані показники якості піномийних косметичних засобів, що забезпечують покращення їх реологічних властивостей / Ю.М. Кордіяка, М.С. Міхалєва, Р.І. Байцар // Вісник Національного університету «Львівська політехніка» Вимірювальна техніка та метрологія. - 2015. - Вип. 75. - С. 107-110. 
5. Байцар P.І. Залежність властивостей піномийних косметичних засобів від твердості води / Р.І. Байцар, Ю.М. Кордіяка // Биомедицинская инженерия и электроника. 2015. - № 1, URL:http://biofbe.esrae.ru/201-988.

6. Вироби парфумерно-косметичні. Правила приймання, відбирання проб, методи органолептичних випробувань.

7. Правила приймання, відбирання проб, методи органолептичних випробувань [Текст]: ДСТУ 5009:2008. - [Чинний від 2009-01-01]. - К.: Держспоживстандарт України, 2009. - 8 с. - (Національний стандарт України).

8. Засоби косметичні для очищення шкіри та волосся. Загальні технічні вимоги [Текст]: ДСТУ 4315:2004. - [Чинний від 2005-07-01]. - К.: Держспоживстандарт України, 2005. - 12 с. - (Національний стандарт України).

9. Визначення піноутворювальної здатності модифікованим методом Росс-Майлса [Текст]: ДСТУ ISO 696:2005 (ISO 696-1975, IDT). - [Чинний від 2007-01-01]. - К. : Держспоживстандарт України, 2007. - 11 с. - (Національний стандарт України).

10. Ердакова, В.П. Современные косметические товары: ассортимент, потребительские свойства, экспертиза качества. Часть 1. Косметические средства по уходу за волосами и кожей головы / В.П. Ердакова. Бийск.-Алт. гос. тех. ун-т, БТИ. 142 с.-Издво Алт. гос. тех. ун-та, 2007.

Цель. Целью работы является исследование качества шампуней различного действия разных производителей, которые реализуются в торговых сетях г. Херсона.

Методика. Исследования проводились с помощью стандартных методик, изложенных в действуюших нормативных документах и соответствующего лабораторного оборудования.

Результаты. По проведенной оценке качества образцов шампуня установлено, что по органолептическим показателям - внешнему виду и ивету, все образиы соответствуют требованиям действующего отечественного стандарта, по запаху два образиа не соответствуют по составу и названию. По физико-химическим показателям все образиь шампуней соответствуют установленным требованиям. Однако, по водородному показателю рН в соответствии с рекомендациями в зависимости от типа волос некоторые образиь имеют низкие значения. На маркировке шампуней ни один из производителей не указал уровень рН, производители трех образцов шампуней не указали частоту использования в зависимости от типа волос. Производители всех образиов шампуней, кроме одного, не указали на маркировке нормативный документ, в соответствии с которым изготовлена данная продукиия.

Требования к качеству шампуней иелесообразно формировать и оценивать с учетом водородного показателя шампуней в соответствии с типом волос. Перспективой дальнейших исследований является формирование потребительских свойств шампуня по результатам проведенного анализа.

Научная новизна. Установлена необходимость проведения исследований качества шампуня с учетом водородного показателя в соответствии с типом волос.

Практическая значимость. Предложенные исследования могут быть использовань во время сертификации шампуня и внесены в действующие нормативные документы. $B$ частности, в общих технических условиях, иелесообразно внесение значений водородного показателя в зависимости от типа волос, для которого предназначены шампуни.

Ключевые слова: шампунь, качество, показатели качества, водородный показатель, типы волос, требования. 
Objective. The objective of the work is to study the quality of shampoos of various types of activity of different manufacturers, which are sold in the retail chains of Kherson city.

Method. The studies were carried out using standard techniques set forth in existing regulatory documents and appropriate laboratory equipment.

Results. According to the conducted assessment of the quality of shampoo samples, it was established that according to the organoleptic parameters - appearance and color, all samples meet the requirements of the current domestic standard, according to the smell, two samples do not correspond to the composition and name. According to physical and chemical indicators, all samples of shampoos meet the established requirements. However, according to the hydrogen index, according to the guidelines for hair type, some samples have low values. On the shampoos labels, none of the manufacturers indicated pH levels, and manufacturers of three shampoo samples did not indicate the frequency of use, depending on the type of hair. Manufacturers of all shampoo samples, except for one, did not indicate on the labels the normative document according to which the given product was manufactured.

The requirements for the quality of shampoos should be formulated and evaluated taking into account the hydrogen index of shampoos according to the type of hair. The prospect of further research is the formation of the consumer properties of the shampoo based on the results of the analysis.

Scientific novelty. The necessity of conducting shampoo quality researches was established taking into account the hydrogen index according to the type of hair.

Practical significance. The offered studies can be used to certify the shampoo and are included in the current regulatory documents. In particular, in general technical conditions, it is expedient to add values of the hydrogen index, depending on the type of hair for which shampoos are prescribed.

Key words: shampoo, quality, quality indices, hydrogen index, hair types, requirements.

Рекомендовано до публікаиї доктором технічних наук, професором ХНТУ Клевиовим К.М. Дата надходження в редакиію 08.02.2019 р. 